International Journal of Social Science (IJSS)

Vol.1 Issue.5 February 2022, pp: 811-818

ISSN: 2798-3463 (Printed) | 2798-4079 (Online)

\title{
THE ROLE OF PROFITABILITY IN MEDIATING CAPITAL STRUCTURE, AND FIRM SIZE ON FIRM VALUE MEDIATED BY PROFITABILITY
}

\author{
By \\ Sajiwo Tri Prakosoㄹ, Diana Pramudya Wardhani ${ }^{2}$, Nur Amalina ${ }^{3}$, Civi Erikawati ${ }^{4}$, Chandra Wisnu Utomo ${ }^{5}$ \\ 1,3,4,5 Retail Management, Faculty of Business and Economics University of Aisyiyah Surakarta \\ ${ }^{2}$ Management, Faculty of Economics, University of Muhammadiyah Ponorogo

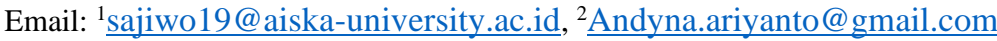

\begin{tabular}{l}
\hline \hline Article Info \\
\hline Article history: \\
Received Nov 17, 2021 \\
Revised Dec 26, 2021 \\
Accepted Jan 28, 2022 \\
\\
\hline Keywords: \\
Capital structure \\
Firm size \\
Profitability \\
Firm value \\
Company Propety Real estat
\end{tabular}

Corresponding Author:

Sajiwo tri Prakoso,

Retail Management, Faculty of Business and Economics

'Aisyiyah University Surakarta

Email: sajiwo19@aiska-university.ac.id

\section{INTRODUCTION}

In this modern era, human needs are not only limited to meeting basic needs, but also extend to secondary needs that can support their activities and welfare, such as the need for vehicles, electronic goods, and travel. Companies that are members of various industrial sectors on the Indonesia Stock Exchange (IDX) are engaged in industries that support these needs. The various industrial sectors referred to in this study are one industrial sector listed on the IDX. Real Estate Sector. Figure 1 shows the housing growth of various industrial sectors over the last six years.

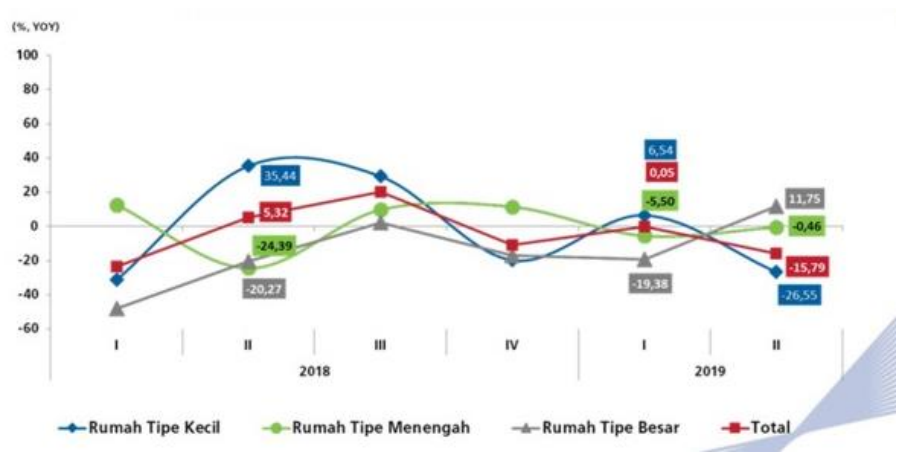

Source: BI, 2019 
The pressure on the property sector in Indonesia, especially housing, continues. Based on a survey conducted by Bank Indonesia (BI), the growth of the Residential Property Price Index (IHPR) in the second quarter of 2019 was only $1.47 \%$ on an annual basis (year-on-year/YoY). This growth rate is the lowest since at least 2012.

According to BI, the increase in residential property prices occurred in all types of houses. The increase in small type house prices slowed from 3.18\% in the first quarter of 2019 to $2.18 \%$ in the second quarter of 2019 . Medium type houses slowed down from 1.82\% YoY to 1.32 YoY. Meanwhile, large type houses slowed down from $1.16 \%$ YoY to $0.92 \%$ YoY. From this data, it can be seen that the slowdown in the increase in residential property prices was greatest for small type houses, namely 1 percentage point. See Figure 2 Residential Property Price Growth (\%YoY).

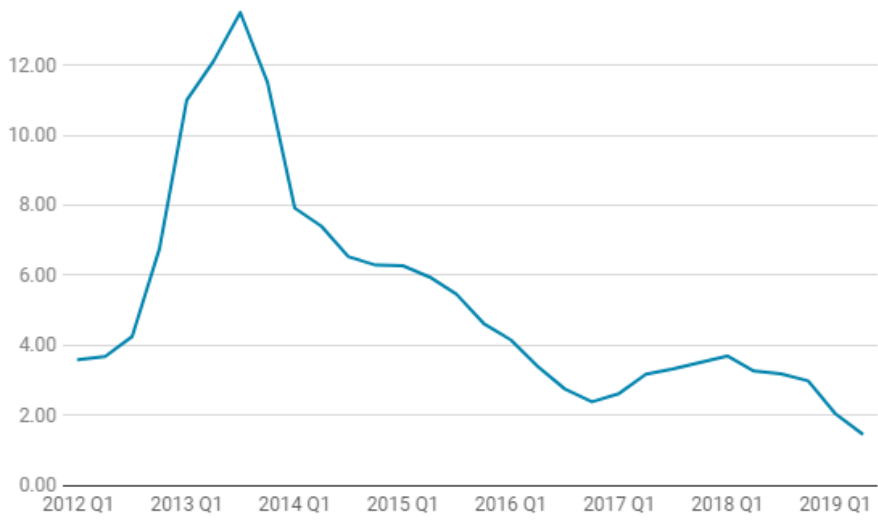

Source: BI, 2019

The slowdown in the increase in the IHPR is also in line with the slowdown in the increase in the costs incurred by households for housing. This is reflected in the increase in the Consumer Price Index (CPI) for the housing cost sub-category which was only $0.8 \%$ on a quarterly basis (quarter-to-quarter/QtQ) in the second quarter of 2019, lower than the previous quarter which was 1.13. \% QtQ. The results of the BI survey also revealed that the number of house sales in the second quarter of 2019 contracted by $15.79 \%$ YoY. Home sales reversed direction from the previous quarter which although thin, still managed to grow by $0.05 \%$ YoY. the increase in the following years is only a very small number (under 1\%), even though companies in this sector produce life support products that are very important for community activities (Andirerei, 2019).

This phenomenon that occurs in various industrial sectors raises our interest to investigate the factors that affect the value of companies (or firms) in these sectors. The rise and fall of stock prices reflects the value of the company. A low stock price indicates the low value of the company, which means that investors are low in interest to invest their funds in the company. Conversely, a high stock price reflects investor confidence in the company, because it is considered to have a high value.

Identification of an already established company is a company that has gone public, the value of the company will be reflected in the market value of its share price. The high stock price of the company will cause its value to increase. Maximizing company value is the main goal of every company, because high company value means increasing the welfare of its owners (Harjito and Martono (2014). The higher the value of the company will increase the interest of investors to invest, so that the company can grow bigger or develop with the capital invested by investors.

Many studies on firm value have been carried out, but have not provided consistent results. Several studies, such as Natsir and Yusbardini (2019) and Nursetya and Hidayati (2020), Tahu dan Susilo (2017) show that profitability has a positive and significant effect on firm value. Research conducted by Oktarima (2017) shows that profitability has no significant effect on firm value. Furthermore, other studies have shown a positive and significant relationship between capital structure and firm value (Natsir and Yusbardini, 2019; and Nursetya and Hidayati, 2020). On the other hand, based on the results of Nursetya and Hidayati's research, 2020, capital structure does not affect firm value. Research conducted by Natsir and Yusbardini (2019) Yusra et., al. (2019) shows that firm size has a significant effect on firm value. In contrast, the results of research by Pantow, et., al. (2015), and Budi and Rachmawati (2014) show that firm size has no significant effect on firm value.

Because there are still gaps in previous research regarding the factors that affect firm value, this study aims to provide empirical evidence about the effect of firm size and capital structure on firm value. The novelty of this research is the use of profitability, especially with ROA as a measuring tool to intervene in the influence of capital 
International Journal of Social Science (IJSS)

Vol.1 Issue.5 February 2022, pp: 811-818

ISSN: 2798-3463 (Printed) | 2798-4079 (Online)

DOI: https://doi.org/10.53625/ijss.v1i5.1326

structure and company size on the value of real estate property companies in various industrial sectors listed on the IDX during 2015-2019.

\section{RESEARCH METHOD}

The data used in this study is secondary data with the variables used are capital structure (DER) $\mathrm{X}_{1}$, Firm Size $\left(\ln\right.$ (Asset) $X_{2}$, profitability (ROA) Y and Firm Value (PBV) Z. Secondary data obtained from real financial statements estate and property listed on the Indonesia Stock Exchange for the period 2015-2019. The data obtained comes from Annual Report data and company performance records taken from www.idx.com. The technique used for this research is the purposive sampling method so that 32 real estate companies are obtained ( Table 1. The analysis used is path analysis with the Sobel test method. In this study, hypothesis testing uses regression and path analysis. Regression tests are carried out to conclude the relationship or effect of the dependent variable on the dependent variable. Riduwan \& Kuncoro (2012) stated that the analysis path is done to determine the relationship between variables and to determine the direct and indirect effects of var independent variable on the dependent variable. Variables that affect the relationship between the dependent variable and the independent variable are called intervening variables.

\begin{tabular}{|c|l|c|c|c|}
\hline \multicolumn{1}{|c|}{ Table 1. Operational Definition } \\
\hline Variables & \multicolumn{1}{|c|}{ Definition } & Proxy & Measurement & Scale \\
\hline Firm Value & $\begin{array}{l}\text { The value of the company itself is one of } \\
\text { the benchmarks for shareholders to } \\
\text { measure the level of success of a } \\
\text { company, which can be seen from its share } \\
\text { price. According to Brigham \& Houston } \\
\text { (2016) }\end{array}$ & PBV & $\frac{\text { Stock market prices }}{\text { Share book value }}$ & Decimal \\
\hline Profitability & $\begin{array}{l}\text { The ratio used in measuring the } \\
\text { effectiveness of the company in generating } \\
\text { profits using assets }\end{array}$ & ROA & $\frac{\text { Net profit }}{\text { Total assets }}$ & Decimal \\
\hline $\begin{array}{c}\text { Capital } \\
\text { structure }\end{array}$ & $\begin{array}{l}\text { The ratio that relates the total debt to the } \\
\text { capital used (Dewi et., al. 2020) }\end{array}$ & DER & $\frac{\text { The total amount of debt }}{\text { Total equity }}$ & Decimal \\
\hline Firm Size & Company Size (Dewi et., al. 2020) & SIZE & Ln(Total asset) & Decimal \\
\hline
\end{tabular}

Table 2. Sampling Criteria

\begin{tabular}{|l|c|}
\hline \multicolumn{1}{|c|}{ Description } & Sampel \\
\hline The total population of property companies for the 2015-2019 period is 32 & 160 \\
$(5 \times 32)$ & \\
Subtracted by the number of companies that did not publish financial reports \\
during the 2015-2019 period \\
Less companies whose financial statements are incomplete during the 2015- \\
2019 period & (5) \\
Outliers & (20) \\
\hline Number of Property Company Data Samples & 115 \\
\hline
\end{tabular}

Source: Analysis Results, 2022

The regression equation model to test the hypothesis is with the following formulation:

$$
\begin{aligned}
& Y=a+b_{1} X_{1}+b_{2} X_{2}+e(\text { Djarwanto dan Pangestu, 2011) } \\
& Z=a+b_{1} X_{1}+b_{2} X_{2}+Y+e(\text { Djarwanto dan Pangestu, 2011) }
\end{aligned}
$$

Path analysis with the Sobel test method is carried out by testing the strength of the indirect effect of the independent variable $(\mathrm{X})$ on the dependent variable $(\mathrm{Z})$ through the intervening variable $(\mathrm{Y})$. The indirect effect of $\mathrm{X}$ to $\mathrm{Z}$ through $\mathrm{Y}$ is calculated by switching paths $\mathrm{X} \rightarrow \mathrm{Y}(\mathrm{b} 1)$ with paths $\mathrm{Y} 1 \rightarrow \mathrm{Y} 2$ (b2) or b1b2. So the coefficient b1b2 $=\left(c^{-} c^{\prime}\right)$, where $\mathrm{c}$ is the effect of $\mathrm{X}$ on $\mathrm{Y} 2$ without controlling for $\mathrm{Y} 1$, while $\mathrm{c}^{\prime}$ is the coefficient of the effect of $\mathrm{X}$ on $\mathrm{Z}$ after controlling for $\mathrm{Y} 1$. The standard error coefficients e1 and e 2 are written as $\mathrm{Se} 1$ and $\mathrm{Se} 2$, the magnitude of the indirect effect Sab is calculated by the following formula:

$$
s b 1 b 2=\sqrt{b 1^{2} S e 2^{2}+b 2^{2} S e 1^{2}+S e 1^{2} S e 2^{2}}
$$


To test the significance of the indirect effect, it is necessary to calculate the t value of the coefficient b1b2 with the following formula:

$\mathrm{t}=\frac{b 1 b 2}{S b 1 b 2}$

This t-count value is compared with the t-table value and if the $\mathrm{t}$-count value is greater than the $\mathrm{t}$-table value, it can be concluded that there is a mediation effect. The hypothesis obtained:

H1: Capital structure has a positive effect on profitability

H2: Firm size has a positive effect on profitability

$\mathrm{H} 3$ : Capital structure has a positive effect on firm value

H4 : Firm size has a positive effect on firm value

H5: Profitability has a positive effect on firm value.

H6: Profitability can mediate the effect of capital structure on firm value

H7: Profitability can mediate the effect of firm size on firm value

\section{RESULTS AND ANALYSIS}

The results of the study using regression testing were used to determine the effect of variables, firm size, and leverage on firm value mediated by profitability. Based on the sample obtained, the results of this test can be seen in the table below:

\subsection{Result}

Table 3. The results of the regression tests of Models 1 and 2 are as follows:

\begin{tabular}{lcc}
\hline \multicolumn{1}{c}{ Variables } & $\begin{array}{c}\text { Model 1 } \\
\text { Profitability }\end{array}$ & $\begin{array}{c}\text { Model 2 } \\
\text { Firm Value }\end{array}$ \\
\hline Leverage & $0,004^{*}$ & $0.000^{*}$ \\
Firm_X2 & $0,009^{*}$ & 0.069 \\
Profitability & & $0.013^{*}$ \\
& & \\
R-Squared & 0,092 & 0,202 \\
Adj. R-Squared & 0,077 & 0,182 \\
F-Hitung & $5.958^{*}$ & $9,809^{*}$ \\
\hline
\end{tabular}

Source: Secondary data processing, 2022

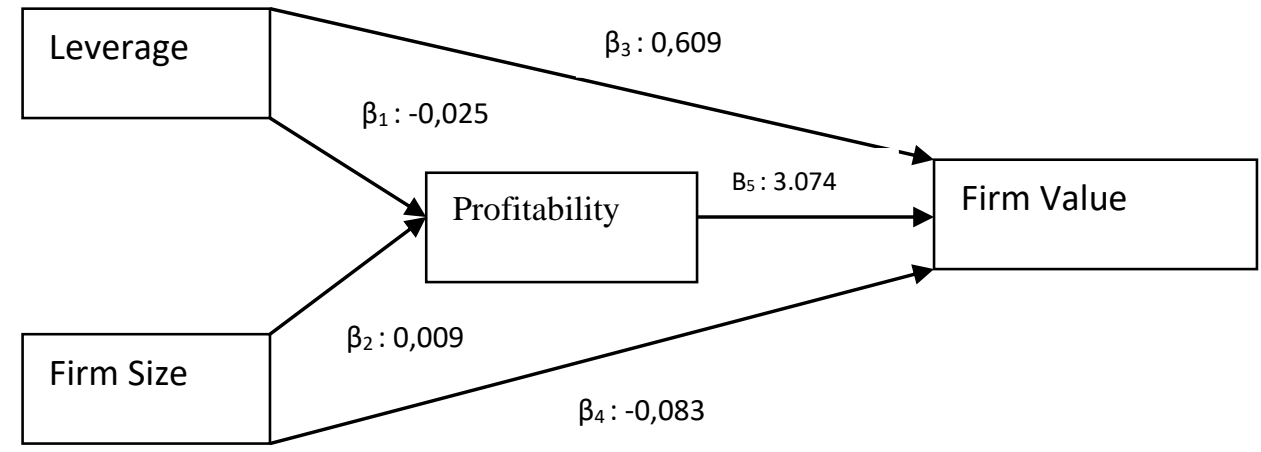

Table 4. Sobel Test Results

\begin{tabular}{lllll}
\hline & \multicolumn{1}{c}{ Inderect Effect } & $\begin{array}{c}\text { Standard error of } \\
\text { Inderect effect }\end{array}$ & $\mathrm{t}_{\text {statistik }}$ & result \\
\hline Path 1 & $\begin{array}{l}\text { Leverage-Profitabilitas }=-0,025 \\
\text { Profitabilitas- Nilai Perusahaan }=0,609\end{array}$ & $\mathrm{~S}_{\mathrm{ab}}=0,088$ & 0,874 & Tidak signifikan \\
Path 2 & $\begin{array}{l}\text { Firm Size-Profitabilitas }=0,009 \\
\text { Profitabilitas- Nilai Perusahaan }=-0,083\end{array}$ & $\mathrm{~S}_{\mathrm{ab}}=0,291$ & 0,095 & Tidak signifikan \\
\hline
\end{tabular}

Source: Secondary data processing, 2022 
International Journal of Social Science (IJSS)

Vol.1 Issue.5 February 2022, pp: 811-818

ISSN: 2798-3463 (Printed) | 2798-4079 (Online)

DOI: https://doi.org/10.53625/ijss.v1i5.1326

The results of testing hypothesis 1 show that capital structure has a negative and significant effect on profitability (Table 3). From this explanation, it can be concluded that a decrease in the DER value will increase the ROA value. This means that the use of less debt will increase the company's profit because there are fewer obligations to be paid by the company so that the company's income does not decrease much to bear the company's obligations. Thus, it can be determined that the capital structure represented by the debt to equity ratio (DER) has a negative effect on profitability. The results of this study are in accordance with research conducted by Nursetya and Hidayati (2020); which shows that capital structure has a negative effect on profitability.

\section{The test Firm Size on Profitability}

The results of testing hypothesis 2 show that firm size has a positive and significant effect on profitability (Table 3). In this study, the larger the size of the company, the higher the profitability. Large companies that are believed to have a more stable and stronger financial condition are considered to be more able to finance the company's operational activities. The company's operational activities that can run well will open up opportunities for the company to get greater profits. Thus, it can be concluded that the size has a positive effect on profitability. The results of this study are in accordance with research conducted by Sughosa et., al. (2020); Nursetya and Hidayati (2020) which shows that firm size has a positive effect on profitability.

\section{The test Capital Structure on Firm Value}

The results of testing hypothesis 3 show that the capital structure (DER) has a positive and significant effect on firm value (PBV) (Table 3). The use of debt can increase the value of the company as long as the use of debt provides benefits and is not above the optimal value. According to Angraini (2015), companies that increase debt are seen as companies that believe in the company's prospects in the future so that it can increase investor confidence which will be shown through the return of company shares which will increase the value of the company. The results of this study are in accordance with research conducted by Natsir and Yusbardini, (2019); and Nursetya and Hidayati, (2020) ; Prakoso (2022)who concluded that DER had a positive and significant effect on PBV.

\section{The test Firm Size on Company Value}

The results of testing hypothesis 4 show that firm size (SIZE) has a positive and insignificant effect on firm value (PBV) (Table 3). The size of the company is not the main focus for investors to buy company shares or investors do not only look at the size of the company's assets, but also look at various factors such as: financial statements, good name and also the policies set by the company's management. And also because the size of the company is assessed from the total assets owned by the company for its operational activities, the larger the size of the company, the greater the funds needed for its operational activities. According to Amalia et., al (2015), companies obtain sources of funds, one of which comes from debt to external parties, so it can be concluded that the larger the size of the company, the greater the debt. Debt withdrawals made by large companies should be able to make companies get large returns in the form of assets as well. Assets that are used as collateral to obtain debt are greater in value than the return on assets received by the company. This shows a lack of solvency. The results of this study are in accordance with research conducted by Atiningsih and Izzaty (2021); Pantow et., al (2015), and Budi and Rachmawati (2014); Prakoso (2022) which state that firm size has no effect on firm value.

\section{The test Profitability on firm value}

The results of testing hypothesis 5 show that firm size (SIZE) has a positive and insignificant effect on firm value (PBV) (Table 3). Indicating a positive direction means that the higher the profitability obtained by the company, the value of the company will increase. The results of this study are in accordance with the perspective of signal theory which explains that the increase in profitability listed in the financial statements is an effort to provide a positive signal to investors related to the company's performance and the growth of business prospects in the future (Rizqia, et al). These efforts can build positive sentiment from investors so that it affects the increase in stock prices in the capital market. An increase in stock prices can increase the value of the company in the eyes of investors. The results of this study are supported by the results of research conducted by Prakoso (2022); Natsir and Yusbardini, 2019; and Nursetya and hidayati, 2020; Khairunisa et., al., (2020) Paramitha, 2020; Garmayuni (2015),Kodongo et., al. (2014); Ju (2011)which proves that profitability has a positive and significant effect on firm value.

\section{The role of profitability as a mediation of capital structure on firm value}

The Sobel test conducted, the resulting mediation effect is not significant, which means there is no mediating effect. This shows that profitability does not mediate the relationship between capital structure and firm value. Thus the sixth hypothesis is rejected. As for the effect of profitability on the capital structure, if the high profit is obtained from sufficient capital, if the capital owned by the company is less then the profit obtained is also difficult. Profitability also affects the value of the company. Signaling theory shows that high profitability is associated with good company prospects, thus triggering investors to increase demand for shares. The increasing demand for shares causes the value of the company to increase. Profitability is one of the factors that can affect the value of the 
company (Hamidy, 2015). Previous research conducted by Erawati and Dewi (2019) ; Sugosha and Arini (2020) showed that profitability did not mediate the relationship between capital structure and firm value.

The role of profitability as a mediation of firm size on firm value

The Sobel test conducted, the resulting mediation effect is not significant, which means there is no mediating effect. This shows that profitability does not mediate the relationship between firm size and firm value. Thus the seventh hypothesis is rejected. The results do not match the Signaling Theory. According to Nurhasanah (2012) in Febria (2013), that large companies usually have large assets. Large company assets will give a signal that the company has good prospects compared to small companies. Results are in line with Akhmadi and Ariandini (2018) which show that profitability does not mediate the relationship between capital structure and firm value. However, the results are also not relevant to Signaling Theory, Putri (2014), that high profitability indicates good company prospects, so investors will respond positively to the signal and the value of the company will increase. This result implies that the larger the size of the company gives a negative signal for the value of the company, compared to small companies, regardless of the level of profitability generated. The profitability aspect is not the main basis for investors in responding to a company's investment policy, but how much an increase in company size through an increase in assets, sales or profits can increase the welfare of shareholders.

\section{CONCLUSION}

The Based on the results of research on the effect of capital structure and firm size on firm value with profitability as an intervening variable with the object of real estate property companies listed on the Indonesia Stock Exchange (IDX) for the 2015-2019 period. From the results of regression testing, it can be concluded as follows: Capital structure has a negative and significant effect on profitability, while firm size has a positive and significant effect on profitability. Partially, capital structure and profitability have a positive and significant effect on firm value, while firm size has a negative and insignificant effect. Profitability has a positive and significant effect on firm value. Profitability as an intervening variable does not mediate the relationship between capital structure and firm size with firm value shown from $t$ arithmetic which is smaller than $t$ table Sobel test..

\section{ACKNOWLEDGEMENTS}

After completing this research, the author received a lot of help and encouragement both morally and spiritually, therefore the author would like to express his deepest gratitude to fellow lecturers of the Faculty of Business and Economics.

\section{REFERENCES}

[1] Erawati, L., \& Dewi, A. S. (2019). Peran Profitabilitas Sebagai Variabel Interverning Dan Pengaruh Struktur Modal Terhadap Nilai Perusahaan.

[2] Nursetya, Radhika Putri Dan Hidayati, Lina Nur. 2020. How Does Firm Size And Capital Structure Affect Firm Value?. Journal Of Management And Entrepreneurship Research Volume 01, Issue 2, P. 67-76, P-Issn 27231658, E-Issn 2723-1666 Available At Http://Ejournal.Unisnu.Ac.Id/Jmer/ Doi:Https://Doi.Org/10.34001/Jmer.2020.12.01.2-7

[3] Riduwan, E. A. K., \& Kuncoro, A. (2012). Cara Menggunakan Dan Memaknai Path Analysis (Analisis Jalur). Bandung: Alfabeta

[4] Brigham, E. F., \& Houston, J. F. (2016). Fundamentals Of Financial Management (Ninth). Boston:Cengage Learning.

[5] Gitman, L. J., \& Zutter, C. D. (2015). Principle Of Managerial Finance (Fourteenth). United States Of America: Pearson Education Limited.

[6] Natsir, Khairina Dan Yusbardini. 2019. The Effect Of Capital Structure And Firm Size On Firm Value Through Profitability As Intervening Variable.Dvances In Economics, Business, Business and management research, volume 145. 8th International Conference on Entrepreneurship Dvances In Economics, Business And Management Research, Volume 145

[7] Andirerei, A., "Kinerja Sektor Industri Bursa Efek Indonesia," Investing.Com, 2019

[8] Harjito, D. And S. Martono, Manajemen Keuangan. Edisi Kedua. Yogyakarta: Ekonisia, 2014.

[9] Gharaibeh, A. M. O. And A. A. A. A. Qader,"Factors Influencing Firm Value As Measured By The Tobin's Q: Empirical Evidence From The Saudi Stock Exchange (Tadawul)," International Journal Of Applied Business And Economic Research, Vol. 15, No. 6, Pp. 333-358, 2017.

[10] Oktarima, B., "Pengaruh Profitabilitas,Likuiditas, Dan Struktur Modal Terhadap Nilai

[11] Perusahaan (Studi Empiris: Pt. Mayora Indah, Tbk. Tahun 2011 - 2015)," Jurnal Sekuritas, Vol. 1, No. 1, Pp.98-107, 2017. 
International Journal of Social Science (IJSS)

Vol.1 Issue.5 February 2022, pp: 811-818

ISSN: 2798-3463 (Printed) | 2798-4079 (Online)

DOI: https://doi.org/10.53625/ijss.v1i5.1326

[12] Hamidy.(2015). Pengaruh Strukturmodal Terhadap Nilaiperusahaan Dengan Profitabilitas Sebagai Variabel Intervening Pada Perusahaan Properti Dan RealEstate Di Bursa Efek Indonesia. Jurnal Ekonomi Dan Bisnis Universitas Udayana(Unud), Bali

[13] Amalia Dewi R, Topowijono, Dan Sri Sulasmiyati. 2015. Pengaruh Ukuran Perusahaan, Profitabilitas, Struktur Modal, Dan Keputusan Investasi Terhadap Nilai Perusahaan Sektor Properti, Real Estate, Dan Building Construction Di Bei Periode 2010-2013. Jurnal Administrasi Bisnis. 23(2)

[14] Rahmawati, S. H., "Analisis Faktor-Faktor Yang Mempengaruhi Nilai Perusahaan(Studi Empiris Pada Perusahaan-Perusahaan Yang Terdaftar Di Bei Tahun 2010-2012," Journal Universitas Riau, Vol. 2, No.1, Pp. $1-15,2015$

[15] Akhmadi Dan Ariandini. 2018. Profitabilitas Dan Dampak Mediasinya Terhadap Nilai Perusahaan (Studi Empirik Pada Perusahaan Sektor Pertambangan Yang Terdaftar Di Bursa Efek Indonesia Periode 2011-2015). Volume Xi, Nomor 1, Desember 2018

[16] Putri, Siti Meilani Wandini. 2014. Pengaruh Dividen Payout Ratio (Dpr), Debt Equity Ratio (Der), Return On Asset (Roa), Dan Size Perusahaan Terhadap Nilai Perusahaan Pada Perusahaan Manufaktur Yang Terdaftar Di Bursa Efek Indonesia (Bei) Periode 2009-2012. E- Journal. Fakultas Ekonomi. Universitas Maritim Raja Ali Haji. Tanjungpinang.

[17]Pantow, Mawar Sharon R, Sri Murni Dan Irvan Trang. 2015. Analisa Pertumbuhan Penjualan, Ukuran Perusahaan, Return On Asset, Dan Struktur Modal Terhadap Nilai Perusahaan Yang Tercatata Di Indeks Lq 45. Jurnal Emba Vol.3 No.1 Maret 2015, Hal.961-971.

[18]Febria, Ririind Lahmi. 2013. Pengaruh Leverage Dan Ukuran Perusahaan Terhadap Profitabilitas. Jurnal Akuntansi, Vol. 1 No.3

[19] Paramitha, Putu Dyah Pradnya. (2020). The Role Of Profitability In Mediating The Effect Of Capital Structure And Liquidity On Firm Value In Food And Beverage Sub-Sector In Indonesian Stock Exchange. Jurnal Ekonomi Dan Bisnis

[20] Jagaditha, 7(2), 80-91 Doi: Https://Doi.Org/10.22225/Jj.7.2.2154.8-19

[21] Atiningsih, Suci Dan Izzaty, Khairina Nur. 2021. The Effect Firm Size On Company Value With Profitability As Intervening Variable And Dividend Policy As Moderating Variable. International Journal Of Economics, Business And Accounting Research (Ijebar) Peer Reviewed - International Journal Vol-5, Issue-4, 2021 (Ijebar) E-Issn: 2614-1280 P-Issn 2622-4771 Https://Jurnal.Stie-Aas.Ac.Id/Index.Php/Ijebar

[22] Kodongo, O., Mokoaleli-Mokoteli T., \& Maina, L., K. (2014). Capital Structur, Profitability And Firm Value: Panel Evidence Of Listed Firm In Kenya. Ssrn Electronic Jorunal, 17 (1), 1-20

[23] Sugosha, Jelita, M., Gede, L., \& Artini, S. (2020). The Role Of Profitability In Mediating Company Ownership Structure And Size Of Firm Value In The Pharmaceutical Industry On The Indonesia Stock Exchange. 7(1), 104-115

[24] Sugosha, M. J., \& Artini, L. G. S. (2020). The Role Of Profitability In Mediating Company Ownership Structure And Size Of Firm Value In The Pharmaceutical Industry On The Indonesia Stock Exchange. Journal Of Management, It And Social Sciences 7(1), 104-115

[25] Tahu, G. P., \& Susilo, D. D. B. (2017). Effect Of Liquidity, Leverage, And Profitability To The Firm Value (Divident Policy As Moderating Variable) In Manufacturing Company Of Indonesia Stock Exchange. Research Journal Of Finance And Accounting, 8(18), 89-98.

[26] Khairunnisa, I., Mismiwati, \& Shalihah, B. M. (2020). Pengaruh Debt To Equity Dan Firm Size Terhadap Nilai Perusahaan Dengan Return On Equity Sebagai Variabel Intervening Pada Perusahaan Yang Terdaftar Di Jakarta Islamic Index (Jii) Periode 2016-2018. I-Finance: A Research Journaln On Islamic Finance, 6(1).

[27] Ju, L., Yu, S. 2011. The Influence Of Profitability On Firm Value With Capital Structure As The Mediator And Firm Size And Industry As Moderators. Investment Management And Financial Innovations. Volume 8, Issue 3, $121-130$

[28]Dewi, G. A. M. S., \& Abundanti, N. (2020). Effect Of Profitability On Firm Valuewith Dividend Policy As A Mediation Variables In Manufacturing Companies. American Journal Of Humanities And Social Sciences Research (Ajhssr), 4(11),330-335.

[29] Ardiana, E., \& Chabachib, M. (2018). Analisis Pengaruh Struktur Modal , Ukuran Perusahaan Dan Likuiditas Terhadap Nilai Perusahaan Dengan Profitabilitas Sebagai Variabel Intervening ( Studi Pada Perusahaan Consumer Goods Yang Terdaftar Di Bei Pada Tahun 2012-2016 ). Diponegoro Journal Of Management,7(2), $1-14$.

[30] Yusra, I., Hadya, R., Begawati, N., \& Istiqomah, L. (2019). Panel Data Model Estimation: The Effect Of Managerial Ownership, Capital Structure, And Company Size On Corporate Value Panel Data Model 
Estimation : The Effect Of Managerial Ownership, Capital Structure, And Company Size On Corporate Value. Journal Of Physics: Conference $\quad$ Series, $1175, \quad 1-6$. Https://Doi.Org/10.1088/17426596/1175/1/012285

[31] Mei, Andanyani Ni Komang Dan Anom, Purbawangsa Ida Bagus. 2019. The Role Of Profitability In Mediating Effect Of Liquidity, Capital Structure, And Sales Growth On Corporate Value In Manufacturing Companies Of Indonesia Stock Exchange. Rjoas, 11(95), November 2019. Doi 10.18551/Rjoas.2019-11.12

[32] Prakoso, Sajiwo Tri. 2022. Dampak Capital Structur, Liquiditas, Ukuran Perusahaan Dan Profitabilitas Terhadap Nilai Perusahaan. Jurnal Manajemen dan Bisnis (J-Mabis) Vol. 1, No. 1. http://ojs.ukb.ac.id/index.php/Jmabis/article/view/405/301 